\title{
Pengaruh Kepemimpinan Transformasional dan Kepuasan Kerja Terhadap Kinerja Karyawan pada PDAM Tirta Satria Kabupaten Banyumas
}

\author{
Purnadi \\ Manajemen, Fakultas Ekonomi dan Bisnis, Universitas Muhammadiyah Purwokerto \\ tugaspurnadi@gmail.com
}

\begin{abstract}
Abstrak
Penelitian ini bertujuan untuk menguji pengaruh secara parsial dan simultan variabel independen kepemimpinan transformasional dan kepuasan kerja terhadap variabel dependen kinerja karyawan pada PDAM Tirta Satria Kabupaten Banyumas. Populasi dalam penelitian ini adalah karyawan tetap PDAM Tirta Satria Kabupaten Banyumas, dengan jumlah sampel 107 responden. Teknik pengumpulan data yang digunakan dalam penelitian ini adalah insidental sampling, sementara teknik analisis data yang digunakan adalah dalam penelitian ini yaitu uji validitas, uji reliabilitas, uji asumsi klasik, analisis regresi linear berganda, dan uji hipotesis. Hasil analisis menunjukan bahwa secara parsial kepemimpinan transformasional berpengaruh signifikan terhadap kinerja karyawan. Kemudian, kepuasan kerja secara parsial tidak berpengaruh signifikan terhadap kinerja karyawan. Secara simultan kepemimpinan transformasional dan kepuasan kerja berpengaruh signifikan terhadap kinerja karyawan
\end{abstract}

Kata Kunci : Kepemimpinan Transformasiona; Kepuasan Kerja; dan Kinerja Karyawan.

\section{Influence Of Transformational Leadership And Job Satisfaction On Employee Performance On PDAM Tirta Satria Banyumas Regency}

\begin{abstract}
This purpose of this research was to examine the effect of partially and simultaneously independent variables Transformational Leadership and Job Satisfaction toward the dependent variable Employee Performance at PDAM Tirta Satria Banyumas Regency. The population in this research were permanent employees of PDAM Tirta Satria Banyumas Regency, the bumber of sample is 107 of respondents. The Data collection technique used in this research was incidental sampling. And data analysis technique that used is in this research was validity test, reliability test, classic assumption test, multiple linear regression analysis, and hypothesis test. The results of the analysis show that partially Transformational Leadership has a significant effect on Employee Performance then Job Satisfaction partially has no significant effect on Employee Performance. Simultaneously transformational leadership and job satisfaction have a significant effect on employee performance
\end{abstract}

Keywords: Transformational Leadership; Job Satisfaction; and Employee Performance 


\section{PENDAHULUAN}

Air bersih merupakan suatu kebutuhan yang utama bagi manusia sehingga ketersediannya harus tetap terjamin dalam kurun waktu, kuantitas, dan kualitasnya. Krisis air bersih di Banyumas dimulai sejak tahun 2015 hingga tahun 2017, krisis air tersebut masih dirasakan sebagian masyarakat di Banyumas. Untuk itu, diharapkan PDAM Tirta Satria mampu memenuhi kebutuhan air bersih di Banyumas yang sering mengalami kekurangan air bersih yang terjadi saat musim kemarau. PDAM berharap dapat meminimalisir keluhan-keluhan masyarakat di seluruh wilayah Banyumas sehingga krisis air dapat teratasi.

Berdasarkan penelitian, PDAM Tirta Satria memiliki 4 Kantor cabang (Unit Purwokerto, Unit Ajibarang, Unit Wangon, dan Unit Banyumas) dan terbagi sebanyak 13 kantor cabang di wilayah Kabupaten Banyumas. Jumlah pelanggan berjumlah 70.382 pelanggan di tahun 2018 sedangkan untuk kapasitas air sekitar 80 liter per detik, dari total kapasitas bisa mencapai 250 meter per detik. PDAM Tirta Satria melayani air bersih hampir sejumlah 65\% penduduk sedangkan 35\% kawasan pemukiman penduduk memenuhi kebutuhan air bersihnya secara mandiri dengan sistem non perpipaan dan menyediakan air secara individual dengan memanfaatkan sumber air tanah melalui sumur dangkal dengan kualitas, kuantitas dan kontinuitas yang terbatas.

Adapun kendala pada PDAM Tirta Satria yaitu ketersediaan sumber air baku berupa mata air yang biaya operasionalnya semakin sulit diperoleh sehingga untuk peningkatan cakupan pelayanan harus memanfaatkan air bawah tanah dengan sumur bor atau mengolah air sungai yang biaya operasionalnya lebih mahal, investasi pembangunan SPAM (Sistem Penyediaan Air Minum) cukup besar 150 sampai dengan 200 juta dan untuk mendapatkan pembiayaan dari APBN (Anggaran Pendapatan dan Belanja Negara) harus ada dana pendamping dari APBD (Anggaran Pendapatan dan Belanja Daerah). Kenaikan harga beberapa komponen biaya seperti BBM (bahan bakar minyak), bahan kimia, dan pendataan teknik sangat memengaruhi biaya operasional penyediaan air minum sehingga harus diikuti dengan kenaikan tarif. PDAM Tirta Satria tetap berupaya melaksanakan penyediaan air minum yang memenuhi standar pelayanan bagi masyarakat dan melaksanakan pengelolaan perusahaan secara profesional dengan peningkatan kompetensi, kesejahteraan, dan soliditas sumber daya manusia yang berkualitas. Adapun tujuan penelitian ini adalah untuk mengetahui pengaruh simultan kepemimpinan transformasional dan kepuasan kerja terhadap kinerja karyawan pada PDAM Tirta Satria Kabupaten Banyumas, serta pengaruh kepemimpinan transformasional dan kepuasan kerja secara parsial terhadap kinerja karyawan pada PDAM Tirta Satria Kabupaten Banyumas.

\section{TINJAUAN PUSTAKA}

\section{Kinerja Karyawan}

Definisi kinerja secara teoritis menurut (Mangkunegara, 2016:67) yaitu berasal dari kata job performance atau actual performance yang berarti prestasi kerja atau prestasi sesungguhnya yang dicapai oleh seseorang. Hasibuan (2012:95) dalam Santoso (2017) berpendapat bahwa kinerja karyawan adalah hasil kerja yang dicapai setiap karyawan sehingga dapat memberikan kontribusi positif terhadap perusahaan atau instansi.

\section{Kepemimpinan Transformasional}

Definisi kepemimpinan transformasional berdasarkan Robbins dan Judge (2014:261) secara teoritis bahwa para pemimpin yang menginspirasi para pengikutnya untuk melampaui kepentingan diri mereka sendiri dan yang berkemampuan untuk memiliki pengaruh secara mendalam dan luar biasa terhadap para pengikutnya. Pendapat lain menyebutkan bahwa, transformational leadership (kepemimpinan transformasional) adalah perspekstif kepemimpinan yang menjelaskan bagaimana pemimpin mengubah tim atau organisasi dengan menciptakan, mengomunikasikan, dan membuat model visi untuk organisasi atau unit kerja dan memberi inspirasi pekerja untuk berusaha mencapai visi tersebut (Wibowo, 2017:327).

\section{Kepuasan Kerja}

Definisi kepuasan kerja secara teoritis menurut Robbins (1996) dalam Badriyah (2015:228) mendefinisikan kepuasan kerja sebagai sikap umum terhadap pekerjaan seseorang, selisih antara banyaknya ganjaran yang diterima seorang pekerja, dan banyaknya imbalan yang mereka yakini harus diterima. Pendapat lain mengenai kepuasan kerja yaitu menurut Steve M. Jex (2002) dalam Sinambela (2017:302) mendefinisikan bahwa kepuasan kerja sebagai tingkat afeksi positif seorang pekerja terhadap pekerjaan dan situasi pekerjaan, kepuasan kerja berkaitan dengan sikap pekerja atas pekerjaannya. 


\section{METODE PENELITIAN}

Penelitian ini merupakan jenis penelitian kuantitatif. Penelitian kuantitatif dinamakan metode tradisional karena metode ini sudah cukup lama digunakan sebagai metode untuk penelitian. Metode ini sebagai metode ilmiah atau scientific karena telah memenuhi kaidah-kaidah ilmiah yaitu konkrit atau empiris, objektif, terukur, rasional dan sistematis. Metode ini disebut kuantitatif karena data peneliti berupa angkaangka dan analisis menggunakan statistik (Sugiyono, 2017:7).

Populasi pada penelitian ini karyawan PDAM Tirta Satria Kabupaten Banyumas berlokasi di Jl. Prof. Dr. Suharso No.52 Purwokerto Kode Pos 53114, Jawa Tengah yang berjumlah 145. Teknik pengambilan Sampel diambil dengan cara purposive sampling, yaitu teknik penentuan sampel dengan pertimbangan tertentu, sehingga sesuai dengan penelitian yang dirancang. Kriteria dalam pemilihan sampel tersebut yaitu karyawan dan karyawati divisi umum, keuangan dan teknik, karyawan dan karyawati yang sudah bekerja lebih dari 1 tahun, tidak termasuk pimpinan. Dalam penelitian ini ukuran sampel minimal yang akan digunakan 107 responden, namun untuk mengantisipasi tidak kembali dan rusaknya kuesioner, peneliti menyebar kuesioner sebanyak 117 responden.

\section{HASIL DAN PEMBAHASAN}

Hasil uji validitas pada penelitian diperoleh bahwa semua indicator yang digunakan untuk mengukur variabel-variabel dalam penelitian ini mempunyai nilai $\mathrm{r}_{\text {hitung }}$ lebih dari $\mathrm{r}_{\text {tabel }}$ atau nilai signifikansi kurang dari 0,05. Maka, dapat dikatakan semua indikator yang digunakan dalam penelitian ini valid. Hasil uji reliabilitas pada penelitian diperoleh bahwa seluruh variabel diketahui nilai $r_{\text {hitung }}$ lebih dari $r_{\text {tabel }}$ sehingga dapat disimpulkan bahwa kuesioner dapat dikatakan reliabel sehingga untuk selanjutnya item-item pada masing-masing konsep variabel layak digunakan sebagai alat ukur.

Hasil uji normalitas dengan One-Sampel Kolmogorov-Smirnov Test diketahui bahwa nilai Kolmogorov-smirnov $Z$ dan asymp. Sig. Sebesar 0,200 semuanya lebih dari 0,05 sehingga dapat disimpulkan bahwa data telah terdistribusi normal. Hasil uji multikolonieritas diketahui bahwa semua nilai tolerance tersebut $\geq 0,1$ dan semua nilai VIF tersebut $\leq 10$, maka dapat disimpulkan model regresi tidak terjadi masalah multikolonieritas. Sedangkan hasil uji heteroskedastisitas dengan menggunakan uji glejser diketahui bahwa semua variabel memiliki nilai signifikansi lebih dari 0,05 , maka tidak ada gejala heteroskedsitas.

Berdasarkan hasil olah data, maka analisis regresi dapat disusun persamaan regresi sebagai berikut : $Y=0,507+0,306 X_{1}+0,120 X_{2}$

di mana :

$\begin{array}{ll}\mathrm{Y} & : \text { Kepuasan Kerja Karyawan } \\ \alpha & : \text { Konstanta } \\ \beta & : \text { Koefisien regresi } \\ \mathrm{X}_{1} & : \text { Kepemimpinan transformasional } \\ \mathrm{X}_{2} & : \text { Kepuasan Kerja } \\ \mathrm{e} & \text { : Standar error }\end{array}$

Persamaan regresi di atas dapat dijelaskan bahwa nilai $\alpha$ sebesar 0,507 yaitu nilai konstanta sebesar 0,507 satuan artinya, jika kepemimpinan transformasional, disiplin kerja dan kepuasan kerja tidak ada perubahan, maka kinerja karyawan sebesar 0,507 satuan. Nilai $\beta_{1}$ sebesar 0,306 artinya koefisien kepemimpinan transformasional naik sebesar satu satuan maka kinerja karyawan akan mengalami peningkatan sebesar 0,306 satuan apabila variabel lain tetap, sedangkan nilai $\beta_{2}$ sebesar 0,120 artinya koefisien kepuasan kerja naik sebesar satu satuan, maka kinerja karyawan akan mengalami peningkatan sebesar 0,120 satuan apabila variabel lain tetap.

Hasil penelitian menunjukkan bahwa nilai koefisien determinasi (Adjusted $R$ Square) sebesar 0,685 atau $(68,5 \%)$. Hal ini menunjukkan bahwa presentase sumbangan pengaruh variabel independen kepemimpinan transformasional $\left(\mathrm{X}_{1}\right)$ dan kepuasan kerja $\left(\mathrm{X}_{2}\right)$ terhadap variabel dependen kinerja karyawan (Y) sebesar 68,5\%, yang dapat diartikan bahwa pengaruh variabel independen terhadap dependen cukup besar sedangkan sisanya sebesar 31,5\% dipengaruhi atau dijelaskan oleh variabel lain yang tidak diteliti dalam model penelitian ini dan perlu banyak diteliti kembali. 


\section{Uji Simultan}

Berdasarkan hasil penelitian dapat diketahui bahwa nilai $\mathrm{F}_{\text {hitung }}$ adalah sebesar 77,878 sedangkan nilai $\mathrm{F}_{\text {tabel }} \mathrm{df}_{1}=(\mathrm{k}-1)=4-1=3$ dan $\mathrm{df}_{2}=(\mathrm{n}-\mathrm{k}-1)=107-4-1=102$ adalah 2,69 , maka $\mathrm{F}_{\text {hitung }}>\mathrm{F}_{\text {tabel }}(77,878>2,69)$ dan nilai signifikansinya adalah sebesar 0,000 lebih kecil dari pada taraf signifikansi 0,05 dapat disimpulkan bahwa uji $\mathrm{F}$ (simultan) diterima, artinya kepemimpinan transformasional dan kepuasan kerja berpengaruh signifikan secara simultan terhadap kinerja karyawan.

\section{Uji Parsial}

Hipotesis pertama dilakukan untuk menguji apakah kepemimpinan transformasional berpengaruh dan signifikan terhadap kinerja karyawan. Berdasarkan hasil uji hipotesis pertama diketahui bahwa nilai $t_{\text {hitung }}$ variabel kepemimpinan transformasional adalah sebesar 3,963; sedangkan nilai $t_{\text {tabel }}$ sebesar 1,65978 pada df $=(n-k-1)=107-3-1=103$ dan nilai signifikansinya adalah sebesar 0,000 . Oleh karena nilai $t_{\text {hitung }}>t_{\text {tabel }}(3,963$ $>1.65978)$ dan nilai signifikansi lebih kecil dari pada taraf signifikansi $(0,000<0,05)$; maka hipotesis pertama diterima, artinya kepemimpinan transformasional berpengaruh signifikan terhadap kinerja karyawan. Kepemimpinan transformasional $\left(\mathrm{X}_{1}\right)$ berpengaruh signifikan terhadap kinerja karyawan (Y) pada PDAM Tirta Satria. Hasil penelitian ini didukung penelitian yang telah dilakukan oleh Putri, dkk (2017) pada karyawan Direktorat Solution Operation Telkomsigma Bandung, Nasution (2018) pada karyawan pada PT Perkebunan Nusantara III Medan, Kartikaningdyah, dkk (2017) pada karyawan Bank Syariah Kota Batam, dan Mamonto,dkk (2016) pada karyawan PT Sulut Makmur Perkasa Kotamobagu.

Hipotesis kedua dilakukan untuk menguji apakah kepuasan kerja berpengaruh dan signifikan terhadap kinerja karyawan. Berdasarkan hasil uji hipotesis kedua, diketahui bahwa nilai $t_{\text {hitung }}$ variabel kepuasan kerja adalah sebesar 1,584, sedangkan nilai $\mathrm{t}_{\text {tabel }}$ sebesar 1,65978 pada df $=(\mathrm{n}-\mathrm{k}-1)=107-3-1=103$ dan nilai signifikansi adalah sebesar 0,116 . Oleh karena nilai $t_{\text {hitung }}<t_{\text {tabel }}(1,584<1.65978)$ dan nilai signifikansi lebih besar dari pada taraf signifikansi $(0,116>0,05)$, maka hipotesis kedua ditolak, artinya kepuasan kerja tidak berpengaruh signifikan terhadap kinerja karyawan.

Kepuasan kerja $\left(\mathrm{X}_{2}\right)$ tidak berpengaruh signifikan terhadap kinerja karyawan $(\mathrm{Y})$ pada PDAM Tirta Satria. Hasil penelitian ini menjelaskan bahwa kepuasan kerja tidak berpengaruh signifikan terhadap kinerja karyawan dan didukung oleh peneliti-peneliti terdahulu. Pada dasarnya kepuasan kerja sesuai dengan teori keseimbangan (equity theory) yang dikemukanan Adam dalam Sinambela (2017:305) bahwa dalam organisasi harus ada keseimbangan. Puas atau tidaknya karyawan merupakan hasil dari perbandingan yang mereka lakukan antara input-outcome dirinya dengan perbandingan input-outcome karyawan lain. Jadi, apabila perbandingan tersebut dirasakan seimbang maka karyawan akan merasa puas. Sebaliknya, apabila tidak seimbang maka dapat menyebabkan ketidakpuasan. Berdasarkan semua pembahasan di atas, maka peneliti menyarankan penelitian selanjutnya untuk menambahkan variabel lain di luar penelitian ini, karena berdasarkan uji koefisien determinasi (Ajusted $R$ Square), variabel independen yang ada pada penelitian ini hanya memiliki pengaruh sebesar $68,5 \%$ terhadap variabel dependen. Sehingga masih banyak variabel lain di luar penelitian ini yang perlu ditambahkan dan diteliti.

\section{PENUTUP}

Kepemimpinan transformasional dan kepuasan kerja secara simultan berpengaruh signifikan terhadap kinerja karyawan pada PDAM Tirta Satria Kabupaten Banyumas. Kepemimpinan transformasional berpengaruh signifikan terhadap kinerja karyawan pada pada PDAM Tirta Satria Kabupaten Banyumas. Kepuasan kerja tidak berpengaruh signifikan terhadap kinerja karyawan pada pada PDAM Tirta Satria Kabupaten Banyumas. Perusahaan dapat mempertahankan kepemimpinan transformasional karena kepemimpinan transformasional mempunyai pengaruh yang signifikan terhadap kinerja karyawan. Seorang pemimpin harus mampu memberikan perlakuan yang adil kepada setiap karyawan. Pihak perusahaan harus tetap meningkatkan kinerja karyawan dengan kepemimpinan transformasional yang baik sehingga penyampaian tugas dapat diterima dengan baik dan karyawan dapat bekerja dengan tertib, teratur, dan sesuai prosedur perusahaan.

Perusahaan dapat memperhatikan kepuasan kerja yang dirasakan seluruh karyawan karena kepuasan kerja tidak mempunyai pengaruh yang signifikan terhadap kinerja karyawan. Seharusnya, perusahaan menggunakan strategi untuk meningkatkan kepuasan kerja karyawan dengan cara memberikan kenaikan jabatan kepada karyawan yang berprestasi, memberikan bonus uang tunai atau bonus tambahan kepada karyawan yang berkinerja baik dalam perusahaan sebagai bentuk apresiasi dari pimpinan untuk karyawan, pemberian bonus yang sesuai dengan prestasi kerja dan tunjangan yang sesuai dengan harapan atau risiko pekerjaan guna meningkatkan kinerja karyawan. 
Penelitian ini memberikan informasi bahwa kepemimpinan transformasional dan kepuasan kerja mempunyai pengaruh sebesar $68,5 \%$. Untuk itu, perlu adanya penelitian lebih lanjut mengenai pengaruh terhadap kinerja karyawan di PDAM Tirta Satria, karena kinerja karyawan tidak hanya dipengaruhi oleh kepemimpinan transformasional dan kepuasan kerja saja tetapi masih banyak faktor lain yang turut mempengaruhinya. Penelitian selanjutnya diharapkan dapat mengembangkan variabel selain kepemimpinan transformasional dan kepuasan kerja, sehingga pada penelitian selanjutnya indikator-indikator setiap variabel dapat dijadikan variabel penelitian agar teori mengenai kepemimpinan transformasional dan kepuasan kerja dapat berkembang dan bermanfaat untuk pengembangan ilmu pengetahuan.

\section{DAFTAR PUSTAKA}

Badriyah, Mila. 2015. Manajemen Sumber Daya Manusia. Bandung: Pustaka Setia.

Cedaryana, Muchlis R. Luddin. dan Supriyati, Yetti. 2018. Influence of Work Discipline, Career Development and Job Satisfaction on Employee Performance Directorate General Research and Development of Ministry Research, Technology and Higher Education. International Journal of Scientific Research and Management (IJSRM) Volume 06 Issue 02.

Ghozali, Imam. 2018. Aplikasi Analisis Multivariate IBM SPSS 25 Edisi 9. Semarang : Badan Penerbit.

Nasution, Muhammad Irfan. 2018. Peran Kepuasan Kerja dan Kepemimpinan Transformasional terhadap Kinerja Karyawan PT. Perkebunan Nusantara III (Persero) Medan. Journal The National Conferences management and Business (NCMAB.

Putri, Mariza Duma. dan Soedarsono, Dewi K. 2017. Pengaruh Kepemimpinan Transformasional dan Employee Engagement terhadap Kinerja Karyawan Direktorat Solution Operation Telkomsigma. Journal e-Proceeding of Management : Vol.4, No.3.

Qodarini, Fika Laela. dan Nugraheni, Rini. 2015. Analisis Pengaruh Disiplin Kerja, Kepuasan Kerja, dan Gaya Kepemimpinan terhadap Kinerja Karyawan (Studi Pada Karyawan Bagian Produksi PT. Nyonya Meneer Semarang). Diponegoro Journal Of Management Volume 4, Nomor 3.

Rahman, Sarli. Purwati, Astri Ayu. dan Yazid, Muhammad Hasbi. (2017). Pengaruh Motivasi, Kepuasan Kerja, dan Disiplin Kerja terhadap Kinerja Karyawan Sabrina City Hotel Pekanbaru. Kurs Vol. 2 No. 2.

Robbins, Stephen. P. dan A, Judge Timothy. 2014. Perilaku Organisasi. Jakarta : Salemba Empat.

Mangkunegara, Anwar Prabu. 2016. Manajemen Sumber Daya Manusia Perusahaan. Bandung: PT Remaja Rosdakarya.

Sanjiwani, I Made Amerthadi. dan Suana, I Wayan. 2016. Pengaruh Kepemimpinan Transformasional, Kepuasan Kerja dan Komitmen Organisasi terhadap Kinerja Karyawan Bagus Hayden Hotel Kuta, Bali. E-Jurnal Manajemen Universitas Udayana, Vol. 5, No. 2.

Santoso, Arief Budi. 2017. Pengaruh Disiplin Kerja, Motivasi, dan Komitmen Organisasi. terhadap Kinerja Karyawan (Pada PT. Bank Negara Indonesia (Persero) Cabang Pamulang. Jurnal mandiri: Ilmu Pengetahuan, Seni, dan Teknologi, Vol. 1, No. 2.

Sinambela, Lijan Poltak. 2017. Manajemen Sumber Daya Manusia. Jakarta: PT Bumi Aksara.

Sugiyono. 2017. Metode Penelitian Kuantitatif, Kualitatif, dan R\&D. Bandung: Alfabeta.

Wibowo. 2017. Perilaku Dalam Organisasi. Depok: Rajawali Pers.

Radarbanyumas.co.id, Antaranews.com diakses pada tanggal 8 desember 2018.

jurnalnasional.ump.ac.id /index.php/MEDEK 